\title{
ÅBNING AF MØDET I ANLEDNING AF DANSK KRI- MINALISTFORENINGS 100-ÅRS JUBILÆUM
}

\section{AF JUSTITSMINISTER FrANK JENSEN}

Jeg vil gerne starte med at takke for indbydelsen. Jeg er både glad og beæret over at få lejlighed til at åbne dette møde i disse flotte og højtidelige omgivelser.

Som formanden nævnte, er der som en væsentlig og værdifuld markering af jubilæet udgivet et særnummer af Nordisk Tidsskrift for Kriminalvidenskab.

Det kommer næppe som nogen stor overraskelse, hvis jeg løfter sløret for, at jeg - midt i forhandlingerne om politiets bevillinger - ikke har haft tid til at læse hele bogen, men jeg har dog haft lejlighed til at orientere mig i den, og jeg er. bestemt imponeret.

Jeg tør slet ikke tænke på, hvor mange arbejdstimer det har kostet kriminaldommer Peter Garde at skrive dette værk, og jeg kan forstå, at både Peter Gardes kone, Kristine, og hønsehunden Zeus også har store aktier i projektet. Det fortjener de alle tre stor tak for!

Det er blevet til et meget imponerende historisk dokument, som ikke alene fortæller om de mange og vægtige debatter, foreningen har stået for, men også belyser de kriminalpolitiske strømninger gennem de sidste 100 år.

Når man ser gengivelsen af debatterne $i$ Kriminalistforeningen - og datterforeningen Dansk Kriminologisk Selskab - får man indtryk af, at foreningen i gamle dage var noget mere blodrig og kampberedt end $\mathrm{i}$ vore dage. Det gælder i hvert fald i forhold til de møder, som jeg har deltaget i i min ministertid. Eller også har der udviklet sig en mere disciplineret måde at udtrykke uenigheder og uforskammetheder på!

Jeg er for så vidt glad for, at den krigeriske adfærd, som foreningen - med rette - anlagde over for en af mine forgængere, nemlig P. A. Alberti, ikke har været nødvendig i nyere tid. For dengang viste foreningen sig at være en frygtindgydende modstander selv for en så magtfuld person som Alberti.

Man kan vel heller ikke undgå at få det indtryk, at foreningen i gamle dage havde en mere direkte indflydelse på den kriminalpolitiske beslutningsproces end $\mathrm{i}$ vore dage. Det skyldes næppe, at foreningens toneangivende medlemmer er mindre driftige eller samfundsbevidste end deres forgængere. Men det skyldes vel nærmere, at den politiske - herunder den kriminalpolitiske - proces har ændret sig, således at mange af medlemmerne via deres professionelle position făr deres meninger frem $\mathrm{i}$ forbindelse med de høringsprocedurer, som i vore dage indgår som et væsentligt element i lovgivningsprocessen.

Det behøver ikke at betyde, at foreningens indflydelse som debatforum er mindsket. Tværtimod forestiller jeg mig at de tværfaglige debatter, som finder sted på foreningens møder, i høj grad er medvirkende til at forme de input, som 
foreningens medlemmer udarbejder der, hvor de nu måtte sidde i samfundsapparatet. Det gælder naturligvis $i$ helt særlig grad for de af medlemmerne, som også sidder i Straffelovrådet, og som vel bl.a. får deres holdninger dannet i samværet og debatterne med foreningens øvrige medlemmer.

Det er slående, når man ser på de temaer, der er taget op i foreningen i de forløbne 100 år, at mange emner går igen og igen. Tænk bare på Hartwig Jacobsens manende ord ved 50-års jubilæet:

- Let resocialiseringen!

- Lad være med at fængsle så meget før dom!

- Lemp den almindelige fængselsstraf!

Det kunne udmærket også gælde som overskrift på et møde i dagens Kriminalistforening. Jeg går ud fra, at det bl.a. er derfor, at et af dagens foredrag handler om kriminalpolitiske bølger.

Der er for så vidt intet mærkeligt i denne bølgegang. Det er jo basale og eviggyldige problemer, som tages op. Løsningsforslagene kan variere over tid - selv om der også her synes at være tale om en vis cyklus, således at gamle ideer med passende mellemrum dukker op igen. Lad mig i den forbindelse nævne nogle strafferetlige emner fra Jusitisministeriets lovprogram for denne folketingssamling, nemlig et forslag om begrænsning af varetægtsfængsling $i$ isolation, et forslag om udvidet brug af samfundstjeneste og forslaget om straffuldbyrdelsesloven.

I et vist omfang skyldes cyklusfænomenet vel, at det samme gør sig gældende i samfundsudviklingen i al almindelighed - og kriminalpolitikken afspejler vel, og skal også afspejle, udviklingen i samfundet $\mathrm{i}$ almindelighed. Og så er der vel også den sandhed i det, at der ikke er noget endegyldigt svar på de store kriminalpolitiske spørgsmål - eller som finnen Patrick Törnudd skal have sagt i 1989: "Kun en charlatan eller en fanatiker vil foregøgle definitive løsninger på disse problemer".

Den nære sammenhæng mellem kriminalpolitikken og den samfundspolitiske udvikling i almindelighed betyder ikke, at disse spørgsmål bør afgøres af den almindelige folkestemning. Der er andre måder at sikre sig, at kriminalpolitikken i nødvendigt omfang svarer til den almindelige politiske opfattelse. Her er jeg enig med Goll, som på årsmødet, vistnok i 1907, afviste folkestemningen som grundlag for straffelovgivningen, idet han sagde: "Alle virkeligt betydelige Reformer paa Strafferettens Omraade herhjemme er i lang Tid blevne gennemførte af et lille energisk og forstaaende Mindretal under Modstand eller Ligegyldighed fra det store Flertals Side".

Det er måske mærkeligt at høre en politiker sige noget sådant, men netop strafferettens område er vel af en sådan karakter, at det er her, det repræsentative demokrati har et af sine kerneområder.

Så selv om foreningens rolle har ændret sig i den forløbne tid, så har forenin- 
gen efter min mening stadig en rolle at spille - eller rettere flere. Også her er jeg enig med Peter Garde.

Sådan som foreningens medlemsskare er sammensat, er det vel stadig det mest alsidige forum, hvor teoretikere og praktikere af enhver art kan mødes, og hvor alle kan komme til orde og forsøge at påvirke dem, der er mere direkte involveret i den kriminalpolitiske proces.

For det andet er foreningen som bekendt grundlag for Nordisk Tidsskrift for Kriminalvidenskab, som fortsat holder en imponerende høj standard, og hvis artikler når ud til langt videre kredse end blot foreningens medlemmer.

$\mathrm{Og}$ for det tredje er foreningen grundsten for det nordiske samarbejde, som det vel i øvrigt er den danske forening, som var den væsentlige igangsætter af, og et samarbejde som siden har været til stor gensidig inspiration og glæde. Karl Schlyter mente allerede ved 50-års jubilæet at kunne konstatere, at vi er "blivit en ända stor familj här oppe i Norden". Sidenhen har dette nordiske samarbejde bl.a. vist sin store betydning deri, at det nordiske sammenhold og ensartede tankesæt har givet Norden en enestående gennemslagskraft i det europæiske samarbejde, som ikke mindst har fundet sted i Europarådets regi, og i det internationale samarbejde, som finder sted.

Nok er foreningen gammel - men ikke forstenet. Den seneste medlemstilgang og de løbende aktiviteter i foreningen taler da også sit tydelige sprog om, at "der er liv i den gamle".

Ved foreningens 50-års dag afsluttede Kars Schlyter sin lykønskning med ordene - "Måtte man om 50 år kunne sige, at foreningens andet halvssekel var ligeså frugtbart som dets første".

Lad mig tage tråden op fra dengang og sige "Måtte man om 100 år kunne sige, at foreningens andet sekel var lige så frugtbart som dets første.” Det skal være mit ønske for Kriminalistforeningens fremtid, og med dette ønske erklærer jeg denne 100-års jubilæumskonference for åben. 